\section{'Gerakan Muncar Rumahku' dan Strategi Mobilisasi Sumber Daya Pada Gerakan Sosial Penyelamatan Lingkungan}

\section{Oleh: Joko Suwarno ${ }^{1}$}

\begin{abstract}
Abstrak
Dalam beberapa tahun terakhir para nelayan di Kecamatan Muncar, Banyuwangi mengalami krisis dalam melakukan aktivitas di Selat Bali mereka akibat penggunaan teknik penangkapan ikan secara desktruktif seperti illegal fishing yang merusak kesinambungan alam. Untuk mengatasi hal tersebut, muncul gerakan lingkungan di tingkat lokal yang menamakan dirinya, 'Gemuruh' atau Gerakan Muncar Rumahku. Gerakan ini bukan hanya bertujuan untuk memberdayakan para nelayan bagi peningkatan kehidupan ekonomi mereka semata, melainkan juga sebagai pemberdayaan (literasi melalui pengetahuan dan praktik serta berorganisasi) yang ditujukan agar para nelayan memiliki pengetahuan yang memadai sehingga dapat memelihara dan menjaga keseimbangan lingkungan hidup yang menjadi sumber mata pencaharian mereka.
\end{abstract}

\section{Kata Kunci:}

Mobilisasi sumberdaya alam dan manusia, gerakan lingkungan, LSM Gemuruh.

\footnotetext{
Abstract

For the last decade, the Muncar fisherman of Banyuwangi have experiencedcrisis in fish catching in the Balistrait. It was particularly triggered by the activities of illegal fishing. In response to the damage caused by the activities of illegal fishing, the locals attempt to establish an environmental movement called 'Gerakan Muncar Rumahku' (Gemuruh). The movement itself aimed at strategy Gemuruh in managing the environmental crisis to use

${ }^{1}$ Joko Suwarno adalah dosen dan peneliti pada Departemen Sosiologi, FISIP Universitas Jember, Jawa Timur.
}

ressources mobilization. Gemuruh do strategy on the fifth type resources mobilization, as following: moral resources, cultural resources, social-organizational resources, human resources, dan material resources.

\section{Keywords:}

Natural and human resources mobilization, environmental movement, Local NGO Gemuruh

\section{Pendahuluan}

Dalam kurun waktu lima tahun terakhir, produksi perikanan laut Kecamatan Muncar terus mengalami penurunan. Pada tahun 2009 produksi perikanan laut Kecamatan Muncar dapat mencapai 32.782,997 ton. Penurunan yang cukup drastis terjadi pada tahun 2010, dimana terjadi penurunan produksi sebesar 32,75 persen dari produksi tahun 2009 sebesar 32.782,997 ton menjadi 22.046,289 ton ditahun 2010 . Sedangkan pada tahun 2013 terjadi kenaikan sebesar 13,98 persen atau naik sebanyak $1.602,475$ ton produksi tahun 2011 yaitu $16.526,715$ ton menjadi 11.459 ton ditahun 2012 (BPS, 2015:17). Hal tersebut dipicu oleh aktivitas nelayan dalam memanfaatkan sumber daya alam melalui penggunaan alat tangkap yang bersifat merusak (illegal fishing dan over fishing) dan tidak memperhatikan aspek berkelanjutan (sustainability) terhadap lingkugan.

Salah satu gerakan lingkungan yang berkembang tahun 2013-an adalah kelompok yang disebut sebagai Gerakan Muncar Rumahku (Gemuruh). Gemuruh merupakan salah satu gerakan sosial yang berada di Kecamatan Muncar. Gemuruh ini bergerak dalam upaya penyelamatan Sumber Daya Kelautan dan Perikanan (SDKP) di daerah pesisir Kecamatan Muncar. Hal tersebut dikarenakan kondisi alam kelautan di Kecamatan Muncar dianggap mengalami kerusakan diakibatkan karena pemanfaatan sumber daya alam yang tidak ramah lingkungan oleh kalangan masyarakat tertentu. 
Gerakan sosial hadir sebagai sarana dalam penolakan ketidakadilan dalam upaya menjamin kelangsungan hidup diatas kerusakan lingkungan yang terjadi. Gerakan lingkungan merupakan salah satu cara dalam mewujudkan jaminan kesejahteraan masyarakat yang terlalu menggatungkan kehidupannya dari sumber daya yang lestari. Memang tidak mudah dalam melakukan gerakan lingkungan, karena hasil yang didapatkan dari gerakan sosial tidak langsung dirasakan oleh masyarakat luas. Selain itu juga, sarana dan prasarana yang digunakan dalam memperjuangkan kelestarian lingkungan juga tidak mudah didapatkan oleh para aktor gerakan.

Gemuruh yang berawal dari kelompok nelayan yang sebelumnya berorientasi pada profit sekarang telah melakukan penyelamatan dengan memanfaatkan berbagai sumber daya yang mereka miliki guna memperbaiki kerusakan dari SDKP. Hal tersebut tidak lepas dari strategi yang dilakukan oleh Gemuruh. Gemuruh sebagai gerakan sosial mampu memobilisasi sumber daya yang dimiliki guna menarik simpati dari masyarakat untuk ikut berpartisipasi dalam melestarikan lingkungan. Selain itu, dalam dinamika menjalankan aksinya juga tidak selalu mulus. Terdapat kendala yang dihadapi. Entah itu kendala yang berdampak besar maupun kendala yang berdampak kecil. Fakta tersebut mememunculkan dua pertanyaan yaitu pertama, bagaimana peran Gemuruh dalam mengatasi kerusakan sumber daya kelutan dan perikanan?; Kedua, bagaimana strategi Gemuruh sebagai gerakan sosial dalam memobilisasi sumber daya.

\section{Metode}

Penelitian ini dilakukan di Kecamatan Muncar dengan menggunakan pendekatan deskriptif kualitatif. Penelusuram sumber data (primer dan sekunder) menggunakan teknik purposive sampling dengan kriteria tertentu sebagai informan. Sedangkan strategi validitas data menggunakan trianggulasi dengan beberapa tahapan diantaranya yaitu: pengumpulan data; reduksi data; penyajian data; dan penarikan kesimpulan atau verifikasi.

\section{Terbentuknya Gerakan Sosial \\ Gemuruh Sebagai}

Kondisi dari penurunan hasil tangkapan ikan dipicu dengan adanya eksploitasi berlebih yang bersifat merusak (illegal fishing) dan penangkapan ikan yang berlebih (over fishing) oleh nelayan. Kedua perilaku eksploratif tersebut sebagai penyumbang kerusakan SDKP atau natural resources scarcity yang akan berdampak pada hasil tangkapan nelayan dalam kurun waktu tertentu. Menurut Kusumah (2015: 52) dengan kata lain maka natural resorcess scarcity, yang ditandai dengan kerusakan lingkungan laut dan semakin menurunnya ketersediaan sumber daya ikan merupakan proses panjang sosio-kultural dan ekonomi nelayan.

Kerusakan terumbu karang ${ }^{2}$ itu sendiri hampir berada disebagian pinggiran pantai. Beberapa tempat di Selat Bali terkenal dengan kerusakan terumbu karang diantaranya adalah Kayu Aking, Teluk Biru, Senggrong dan Kapal Pecah. Pada beberapa tempat yang mengalami kerusakan, sekitar 80\% dikategorikan dalam rusak parah. Dengan terjadinya kerusakan terumbu karang, masyarakat mendorong pemerintah untuk membuat kebijakan terkait dengan pembuatan laut lindung (fish sanctuary). Kebijakan politik tersebut tertuang dalam Peraturan Daerah Kabaupaten Banyuwangi No.35 Tahun 2003 tentang Penetapan, Pelestarian dan Pengelolaan Kawasan Laut Lindung Perairan Kayu Aking Di Muncar Kabupaten Banyuwangi.

\footnotetext{
${ }^{2}$ Berdasarkan The Status of Coral Reefs of The World 2000, di dunia ini diperkirakan terumbu karang yang rusak sekitar 27\%. Jika ini tidak diantisipasi maka diperkirakan pada tahun 2010 kerusakan akan mencapai 40\%, dan tahun 2030 bisa mencapai 58\%. Sementara itu, Indonesia yang saat ini memiliki 18\% dari terumbu karang dunia, juga tak jauh beda. Hanya sekitar 6\% yang tergolong bagus dan sekitar 30\% telah rusak (Satria, 2009: 53)
} 
Sumber Daya Kelautan dan Perikanan (SDKP) yang juga mengalami kerusakan adalah ekosistem mangrove ${ }^{3}$. Kondisi ekosistem mangrove yang banyak mengalami kerusakan berada di pinggiran pantai Kecamatan Muncar. Kerusakan dari mangrove sendiri diakibatkan oleh eksploitasi dari masyarakat yang mengeksploitasi mangrove itu sendiri demi tujuan-tujuan tertentu. Pengrusakan mangrove tidak lain adalah masyarakat sekitar. Masyarakat sekitar pesisir, memanfaatkan kekayaan biota laut dikawasan mangrove yang memiliki harga ekonomis.

Akan tetapi, pada kondisi tersebut belum memanfaatkan sumber daya kelautan dan perikanan secara maksimal ${ }^{4}$. Hal tersebut seperti yang diungkapkan Kusumah (2015: 92) potensi kelautan dan pesisir yang besar ini belum sepenuhnya dimanfaatkan secara optimal. Kerusakan lingkungan laut dan pesisir yang terjadi karena fenomena alam itu sendiri dan juga karena kegiatan di atasnya. Hal tersebut nampak pada alur konseptual perilaku nelayan dalam memanfaatkan dan mengelola sumber daya kelautan dan perikanan.

Dalam dinamika perkembangannya, pembentuan Gemuruh merupakan inisiatif dari masyarakat nelayan itu sendiri. Terbentuknya Gemuruh berawal dari Kelompok Usaha Bersama (KUB) nelayan yang berorientasi profit, namun sekarang mengalami transformasi menjadi gerakan sosial yang bergerak dalam pelestarian

\footnotetext{
${ }^{3}$ Indonesia sudah kehilangan sebagian besar mangrovenya. Dari 1982 hingga 2000, Indonesia telah kehilangan lebih dari setengah hutan manrove dari 4,2 juta hektar hingga 2 juta hektar (dalam

http://www.greenpeace.org/seasia/id/PageFile s/533771/Laut\%20Indonesia\%20dalam\%20Kr isis.pdf diakses pada 21 Maret 2016 pukul 20.20 WIB)

4 Potensi MYS (Maximum Sustainable Yield) sumber daya perikanan diperkirakan sekitar 6,4 juta ton pertahun. Sedangkan pemanfataanya masih sekitar 80\% dari MYS yaitu 5,12 ton pertahun.
}

lingkungan. Dari dinamika transformasi yang dilakukan oleh Gemuruh sebagai gerakan sosial yang dahulunya berbentuk KUB Maju Jaya yang berorientasi pada profit sekarang menjadi organisasi gerakan sosial sebagai penyelamat SDKP di Kecamatan Muncar dan perairan Selat Bali. Hal tersebut dapat dilihat pada Gambar 1 sebagai berikut.

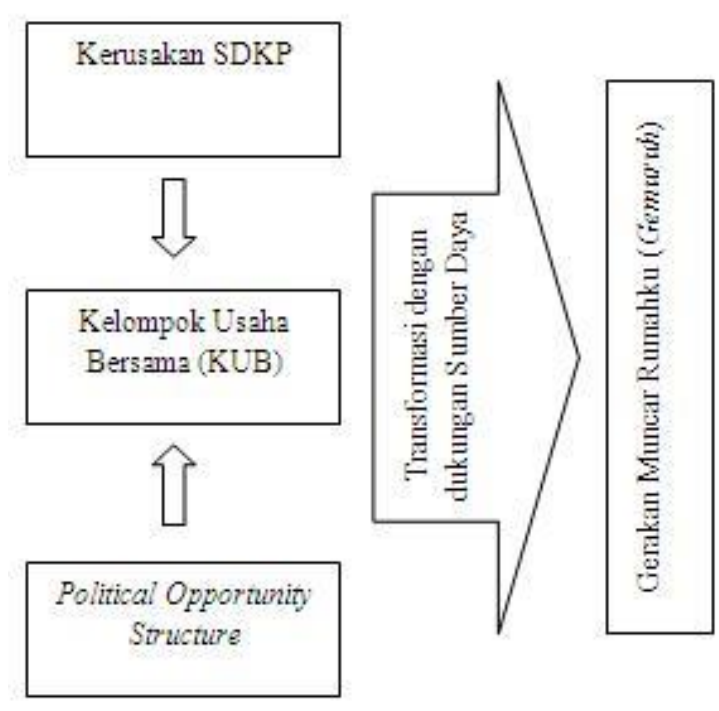

Gambar.1.

Terbentuknya Gemuruh Sebagai Gerakan Sosial

Gemuruh terbentuk atas kondisi sumber daya kelautan dan perikanan yang megalami kelangkaan. Hal tersebut karena tindakan Gemuruh merupakan bentuk reaksi kesadaran dari sekelompok masyarakat yang bertujuan mengembalikan kembali kerusakan yang selama ini telah terjadi. dengan aksi tersebut bertujuan untuk mengembalikan fungsi dari laut yang akan menjamin keberlangsungan kehidupan dan penghidupan masyarakat nelayan. Seperti yang diungkapkan Kusumah (2015: 251), tindakan sosial nelayan melalui pengembangan kelompok sosial menjadi manifestasi kesadaran kelompok nelayan atas lingkungannya. Kesadaran ekologi yang ditumbuhkan nelayan, pada dasarnya merupakan upaya nelayan untuk mengembalikan fungsi lingkungan alam pada kondisi semula. Nilai paling mendasar dari tumbuhnya kesadaran sosial-ekologis adalah sebagai dorongan 
normative nelayan untuk memberikan hak atas jaminan sosial dari lingkungan.

\section{Strategi Gerakan Sosial Dalam Mobilisasi Sumber Daya}

Peran Gemuruh sebagai organisasi gerakan sosial dapat dikategorikan dalam beberapa aksi penyelamatan SDKP diantaranya yaitu dengan patroli pengawasan, pelestarian rumah ikan (fish appartment), penanaman terumbu karang dan mangrove. Dengan serangkaian aksi gerakan tersebut, Gemuruh mempercayai dapat mencapai tujuan gerakan. Dalam strategi menjalankan aksinya, Gemuruh didukung dengan sumber daya yang ada. Sumber daya tersebut di mobilisasi dalam melancarkan aksinya. Sumber daya ini berupa antara lain berupa: pengetahuan, uang, media, tenaga kerja, kesetiakawanan, legitimasi dan dukungan internal dan eksternal dari elit penguasa (Maarif, 2010: 69).

Setiap Social Movement Organization (SMO) harus mampu mengelola sumber-sumber material, seperti pekerjaan (jobs), penghasilan (income), tabungan (saving), serta sumber-sumber non-material seperti wewenang (authority), komitmen moral (moral commitment), kepercayaan (trust), persahabatan (friendship), kemampuan (skill) dan sebagainya (Sukmana, 2013: 45). Sumber daya ini sangat penting dalam organisasi gerakan sosial penyelamatan lingkungan seperti Gemuruh. Hal ini dikarenakan agar mampu menjaga eksistensi gerakan dalam mencapai tujuan.Sehingga perubahan yang diinginkan dapat tercapai oleh Gemuruh.

Hal tersebut seperti yang diungkapkan oleh McCarthy dan Zald (1997: 1217) strategi dan taktik dalam mobilisasi sumber daya. Mobilisasi sumber daya tidak hanya berbentuk interaksi antara gerakan dan otoritas yang diterima, tetapi organisasi gerakan sosial juga memiliki langkahlangkah strategis. Contohnya memobilisasi pendukung, menetralkan dan mentransformasi pemimpin publik menjadi simpatisan dan mencapai tujuannya. Dilema dalam memilih taktik, ketika mencapai suatu tujuan yang mungkin bersinggungan dengan pencapaian tujuan yang lainnya. Meski begitu, taktik berperan penting dalam kompetisi dan kerjasama antar organisasi.

\section{Mobilisasi Moral Resources}

Pada bagian awal Edward dan McCarthy (dakam Snow dkk, 2004: 125) menjelaskan secara umum moral resource adalah legitimasi, dukungan, solidaritas, simpati masyarakat dan tokoh terkenal. Dalam hal ini, legitimasi merupakan dasar dari moral resources. Karena dukungan, simpati dan solidaritas diperoleh melalui suatu proses legitimasi, dan dalam setiap tahap gerakan sosial terkadang menghadapi kesulitan mendapatkan sebuah legitimasi berupa simpati masyarakat atau dukungan tokoh.

Legitimasi yang didapatkan oleh gerakan sosial merupakan proses panjang dari solidaritas dalam organisasi gerakan sosial melalui perjuangan aksi mencapai tujuan. Dengan aksi yang diperjuangkan oleh organisasi gerakan sosial akan memunculkan simpati dari masyarakat untuk ikut berpartisipassi dalam aksi yang dilakukan. Bentuk simpati masyarakat dengan ikut berpartisipasi dalam aksi gerakan sosial akan menciptakan legitimasi atas organisasi gerakan sosial. Hal tersebut dapat dilihat dalam kerangka sebagai berikut.

Aktor Gemuruh menunjukkan sikap sukarelawan berlebih yang disebut sebagai hyper voluntary. Para aktor gerakan sosial secara sukarela mengorbankan waktu, tenaga, pikiran bahkan uang yang mereka miliki dalam mencapai tujuan Gemuruh. Sikap ini dibutuhkan (needs), dibangun dengan baik (well-development) dan dipelihara (maintained) dalam interaksi antar angotanya. Sikap hyper voluntary tersebut akan memunculkan komitmen antar aktor gerakan sosial yang menimbulkan solidaritas dalam gerakan sosial. Menurut Maarif (2010: 69) komitmen dari peserta gerakan dipelihara melalui pembentukan identitas kolektif secara berkelanjutan, yang bermanfaat untuk menjaga organisasi gerakan melalui 
hubungan antar pribadi anggotanya. Bentuk solidaritas antar anggota Gemuruh ditunjukkan dengan komitmen dalam merintis gerakan sosial.

Dalam perjalanannya, Gemuruh mendapatkan banyak dukungan dari kalangan nelayan, pemuda serta sesama komunitas yang peduli terhadap lingkungan. Cara penyadaran oleh Gemuruh dengan memberikan contoh kegiatankegiatan yang positif melalui aksi penyelamatan SDKP. Selain kelompok nelayan, terdapat juga tambahan dari kelompok sekitar yang bernama Laros Jenggirat Munstik ${ }^{5}$. Bahkan kelompok ini meminta jandwal kegiatan sendiri pada setiap hari jum'at dijadikan sebagai hari bersih-bersih sampah di pantai. Melalui interaksi dengan kelompok lain, muncul pula identitas kelompok. Identitas ini tidak bisa diidentikkan sebagai atribut yang sama, tetapi lebih mengacu pada perasaan yang sama dan kadaan yang sama ketika mereka sama-sama tertekan oleh kelompok lain yang dominan atau mayoritas (Silaen, 2004: 42). Identitas kelompok bersama ini ditunjukkan dengan kepedualian atas kerusakan SDKP yang terjadi di Kecamatan Muncar dan perairan Selat Bali. Rasa tanggung jawab yang bangun sebagai warga negara yang telah memanfaatkan sumber daya alam secara berlebih dan tidak memperdulikan aspek berkelanjutan merupakan reaksi terhadap peran negara dan swasta yang acuh terhadap kerusakan SDKP yang terjadi selama ini.

Proses legitimasi didapatkan Gemuruh dari kalangan nelayan dan pemuda yang peduli lingkungan. Hal tersebut berbeda dengan Edward dan McCharthy ${ }^{6}$ dalam jika legitimasi didapatkan dari para elit-elit lokal yang ada pada suatu daerah tersebut.

${ }^{5}$ Laros Jenggirat Munstik merupakan singkatan dari Laros Jenggirat Muncar Suporter Fanatik. Kelompok ini merupakan pendungkung klub sepak bola Persewangi yang berdomisili di daerah Muncar.

${ }^{6}$ Baca Edward, Bob dan John D. McCarthy dalam Snow dkk. 2004. Resources and Social Movement Mabilization: The Blackwell companion to social movement. United Kingdom: Blackwell Publishing Ltd hal.126
Hal ini menjadi unik ketika para elit lokal bersikap acuh terhadap kerusakan lingkungan. Akan tetapi kalangan pemuda dan nelayan yang antusias dalam merspon isu kerusakan lingkungan serta berberan aktif dalam penyelamatan kerusakan lingkungan dalam menciptakan kondisi SDKP yang lestari di Kecamatan Muncar dan perairan Selat Bali. Bahkan dukungan yang di dapatkan tidak hanya dari Muncar saja, daerah di luar Kecamatan, Kabupaten bahkan Provinsi juga berpartisipasi dalam kegiatan Gemuruh.

\section{Mobilisasi Cultural Resources}

Di Kecamatan Muncar juga terdapat tradisi kebudayaan masyarakat lokal yang diselenggarakan pada setiap tahunnya dengan sebutan petik laut ${ }^{7}$. Kusumah menjelaskan (2015: 244) petik laut dilaksanakan setiap bulan Muharam atau Syuro dalam penanggalan Jawa. Menurut legenda setempat ritual ini dimulai dengan kedatangan Sayid Yusuf ketika masuk ke Muncar bersamaan dengan penyebaran agama Islam di Blambangan. Tradisi kebudayaan petik laut tersebut merupakan suatu bentuk syukur kepada Tuhan yang telah menjamin ketersediaan ikan di laut Selat Bali. Ritual tersebut disisi lain merupakan cara penghormatan masyarakat lokal terhadap laut. Bentuk pengormatan atas laut ditunjukkan dengan serangkaian sesajen yang nantinya akan di larung ke laut. Gemuruh seringkali melakukan aksinya dengan ikut berpartisipasi pada ritual petik laut dengan melakukan penanaman terumbu karang beserta rumah ikan. Mereka memanfaatkan momen ritual tahunan petik laut agar aksi mereka dapat dilihat oleh masyarakat luas dan akan menambah legitimasi, simpati dan solidaritas dari pihak lain.

\footnotetext{
${ }^{7}$ Petik laut merupakan tradisi kebudayaan masyarakat lokal Muncar yang diselenggarakan pada setiap tahunnya. Masyarakat lokal mempercayai jika petik laut merupakan bentuk terimakasih atas diberikannya hasil tangkapan ikan. Tujuan dari petik laut agar para nelayan agar diberikan keselamatan dan kelancaran saat melaut serta untuk menjamin tersedianya perikanan di Selat Bali yang melimpah.
} 
Selain adanya nilai dan norma yang mengajarkan masyarakat lokal untuk mengajarkan peduli menjaga lingkungan, para aktor Gemuruh menjalankan aksinya dengan keterbatasan pengetahuan yang mereka miliki. Peneliti menemukan jika Gemuruh melakukan pelestarian dengan mengambil, menyamai dan menanam bibit mangrove sesuai dengan peengetahuan dan pengalaman yang dimilikinya terkait jarak, waktu, dan kedalaman untuk pelestarian mangrove.

Edward dan McCarthy (dalam Snow dkk, 2004: 126) cultural resources, merupakan produk kultur yang dimiliki oleh aktor gerakan sosial. Sumber daya ini sangat erat kaitannya dengan konsep stock of knowledge yang dimiliki oleh aktor gerakan sosial. Kategori ini cultural resources termasuk gerakan atau masalah terkait produksi seperti musik, pengetahuan, majalah, surat kabar, dan film atau video. Produk budaya seperti ini memfasilitasi perekrutan serta sosialisasi dari gerakan baru penganut dan membantu keadilan kepada mereka kesiapan dan kapasitas untuk bertindakan.Dengan adanya budaya petik laut, para aktor Gemuruh mengetahui adanya arena yang memberikan kesempatan untuk meningkatkan legitimasi dari masyarakat. Gemuruh dengan pengalaman para aktornya dalam penyelamatan SDKP secara sederhana membuat prosedur atau cara tersendiri dalam penyelamatan SDKP. Penggunaan bahan-bahan dari alam seperti bambu, rumbai-rumbai, penyemaian bibit mangrove merupakan bentuk cultural resources yang dimobilisasi oleh Gemuruh.

\section{Mobilisasi Social-Organizational Resources}

Edward dan McCarthy (dalam Snow dkk, 2004: 127) menjelaskan SocialOrganizational resources, merupakan kategori yang didalamnya termasuk organisasi sosial yang sengaja dibuat secara spesifik untuk mencapai tujuan gerakan. Terdapat tiga hal yang bisa dikategorikan sebagai sebuah social-organizational resources yakni: infrastruktur; jaringan sosial; dan organisasi. Gemuruh membentuk kelembagaan struktur organisasi dengan pembagian dalam beberapa bidang. Gemuruh juga memanfaatkan prasarana publik seperti dermaga pelabuhan dan Aula TPI Muncar dalam mempersipakan aksinya. Selain itu, Gemuruh juga mempunyai akses pada media sosial. Penggunaan media sosial oleh Gemuruh sebagai upaya dalam mendapatkan dan mempertahankan partisipannya untuk mendapatkan dukungan pendanaan organisasi gerakan sosial.

Pembentukan struktur organisasi dalam gerakan sosial sangat diperlukan. Hal ini dikarenakan gerakan sosial mudah mengalami kegagalan. Sehingga dengan adanya akan menjaga eksistensi dari organisasi gerakan sosial itu sendiri agar dapat eksis dalam memperjuangkan gerakan penyelamatan lingkungan yang telah banyak mengalami kerusakan. Kusumah (2015: 237) menjelaskan pelembagaan atau institusionalisasi adalah sebuah konsep sosiologi untuk menjelaskan bahwa sesuatu telah menjadi bagian dari dunia sosial. Begitu pula dengan Gemuruh yang mempunyai struktur oragnisasi sebagai respon terhadap kelangkaan SDKP yang terjadi di Kecamatan Muncar dan perairan Selat Bali. Struktur organisasi Gemuruh sendiri dapat dilihat pada gambar 2, yang terdiri dari koordinator, sekretaris, bendahara, koordinator pengawasan, koordinator ekowisata dan, koordinator pelestarian.

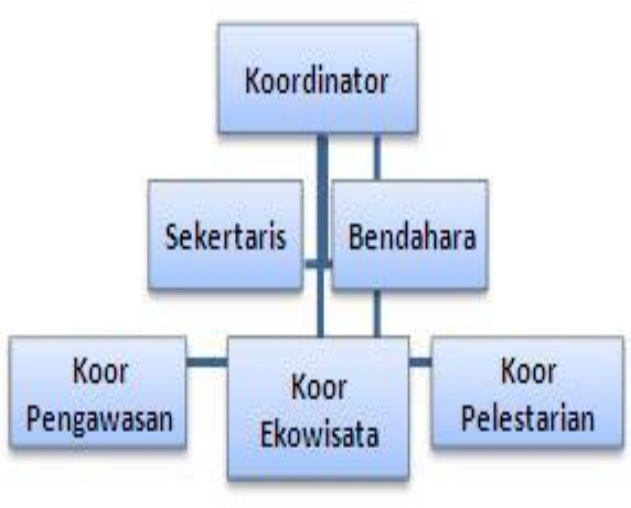

Gambar. 2. Struktur Organisasi Gemuruh 
Gemuruh menggunakan berbagai fasilitas publik dalam melaksanakan aksinya. Berdasarkan observasi yang dilakukan peneliti, pada beberapa kegiatan seperti Rapat Kerja (Raker) tahun 2016 Gemuruh menggunakan Aula Tempat Pelelangan Ikan (TPI) Kecamatan Muncar sebagai tempat dalam merumuskan proyeksi kegitan. Selain itu juga, armada kapal yang dimiliki Gemuruh untuk melakukan penanaman terumbu karang berada di Pelabuhan Muncar. Hal ini menunjukkan jika Gemuruh menggunakan fasilitas publik dalam melakukan memobilisasi sumber daya.

Faktor penting mengapa kelompok lebih mudah untuk melakukan mobilisasi karena kelompok memiliki jaringan komunikasi yang sudah mapan (established), terdapat anggota dengan kemampuan kepemimpinan, dan adanya partisipasi tradisional dari para anggotanya (Sukmana, 2013: 46). Dalam hal ini yang menjadi fokus utama adalah jaringan sosial, yang memiliki posisi sebagai sumber daya yang signifikan untuk mendapatkan suatu legitimasi aktivitas dari gerakan termasuk legitimasi untuk mengakses sumber daya yang lainsebut saja uang (dalam Snow dkk, 2004: 127).

Pembentukan ekowisata oleh Gemuruh merupakan bentuk dari socialorganizational resource dalam kategori social network dalam menjamin tersedianya sumber pendanaan pada organisasi gerakan sosial dalam menjalankan aksinya. Ekowisata Teluk Biru merupakan strategi dalam mendapatkan sumber pendanaan untuk diakumulasikan dalam aksi yang dilakukan oleh Gemuruh.

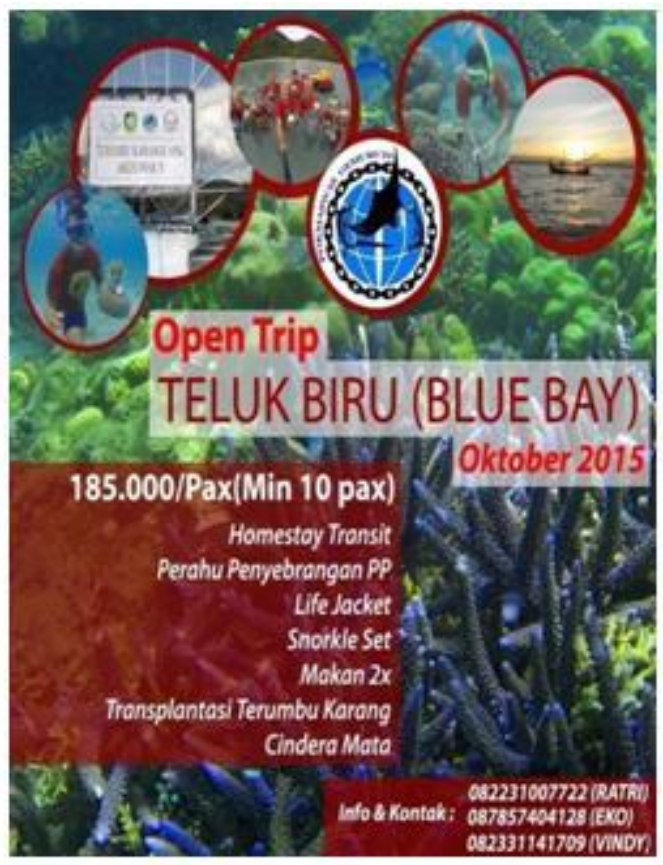

Gambar. 3. Paket Ekowisata Teluk Biru

Kontruksi yang bersifat sukarela yang berlebihan (Hyper Voluntaristic) menurut teori mobilisasi sumber daya mengenalkan citra gerakan sosial baru (GSB) sebagai sebuah korporasi industri multinasional yang dijalankan oleh struktur manajerial dengan kualifikasi tinggi berikut etos kental mencetak profit. Ia mensyaratkan kemampuan bernalar dan rasionalitas bagi para partisipasinya (Singh, 2010: 136-137). Meskipun tidak begitu mendapatkan keuntungan profit yang banyak dari adanya ekowisata Teluk Biru menjadikan sumber pendanaan kegiatan Gemuruh. Bahkan selama ini sumber pendanaan utama Gemuruh dalam pelestaraian SDKP secara swasembada mandiri $90 \%$ berasal dari adanya ekowisata.

\section{Mobilisasi Human Resources}

Dalam setiap organisasi gerakan sosial selalu memiliki kebutuhan dalam mencapai tujuannya. Kebutuhan dalam organisasi gerakan sosial diantaranya seperti legitimasi serta akses dalam memperoleh sumber pendanaan. Melalui kebutuhan human resources, kebutuhan organisasi 
gerakan sosial dapat terpenuhi. Hal tersebut seperti yang diungkapkan oleh Edward dan McCarthy (dalam Snow dkk, 2004: 127) bahwa human resources, merupakan kategori yang didalamnya termasuk aktor beserta pengalaman, dan keahliannya. Ini lebih kepada individu-individu yang memiliki sesuatu seperti keterampilan tertentu, keahlian tertentu, dan pengalaman yang sesuai dengan kebutuhan suatu gerakan sosial.

Gemuruh memobilisasi aktornya untuk mendapatkan sumber pendanaan dari partisipannya. Salah satu contohnya sebagai bentuk mobilisasi para aktornya adalah dengan memanfaatkan media sosial seperti pembuatan akun facebook, bloger, instagram dan BBM (Black Barry Mesengger) dalam mengajak masyarakat untuk ikut berpartisipasi dalam pelestarian lingkungan. Terkadang meraka mereka juga mengganti profile picture dengan kegaitan Gemuruh yang mereka lakukan dalam pelestarian SDKP. Sehingga social network yang terbangun dari kontak aktor Gemuruh dalam mensosialisasikan pelestarian lingkungan dapat tersampaikan kepada para partisipannya. Selain itu juga, Gemuruh juga seringkali mengajak OSIS SMA di sekitar wilayah Kecamatan Muncar dengan surat menyurat secara formal yang ditujukan pada pihak sekolah. Ini merupakan keahlian lain Gemuruh sebagai organisasi gerakan sosial secara adaministrasi dalam mendapatkan partisipan. Seringkali, undangan yang ditujukan pada sekolah dalam pelestaran mangrove di pesisir pantai Kecamatan Muncar.

Gemuruh memobilisasi para aktornya dengan keahlian tertentu dalam memenuhi kebutuhan gerakan sosial. Dengan keahlian masing-masing setiap aktor seperti mengajak para partisipan Gemuruh dengan cara berpomosi melalui pamanfaatan akses pada media sosial, pembuatan akun media sosial, manajerial Gemuruh atas kontrol terhadap partisipan yang berkunjung dengan paket wisata ke Teluk Biru dalam pelestarian termbu karang dan pembuatan surat undangan kepada sekolah-sekolah di sekitar Kecamatan Muncar.

\section{Mobilisasi Material Resources}

Material resources adalah tipe yang terdiri dari sumber-sumber ekonomi yang umumnya disebut modal finansial dan modal fisik. Termasuk didalamnya antara lain adalah; uang, properti atau bangunan, kantor dan lain sebagainya. Uang merupakan hal yang sangat penting bagi gerakan sosial. Seberapa besarpun sumber daya lain yang dimiliki atau dukungan anggota, mobilisasi tidak akan berjalan kalau tidak ada yang membiayai (Snow dkk. 2004: 128). Gemuruh sebagai organisai gerakan sosial memobilisasi beberapa aset yang dimilikinya seperti para aktor, uang, sekertariat, seperangkat komputer, mesin printer, jaket pelampung, alat snorkeling serta satu armada perahu dalam penyelamtan SDKP di Kecamatan Muncar dan perairan Selat Bali. Pada awal berkembangnya Gemuruh terdapat hanya beberapa material resources yang dimiliki oleh KUB-Maju Jaya. Beberapa aset yang dimiliki Gemuruh pada saat itu diantanya yaitu sekertariat, seperangkat komputer, mesin printer, jaket pelampung, alat snorkeling serta satu armada perahu. Sumber daya materi ini dirasa minim jika melihat kegiatan yang telah dilakukan oleh Gemuruh saat ini.

Selain itu yang tidak kalah pentinganya adalah mobilisasi non-material dalam oraganisasi gerakan sosial. Aset nonmaterial dalam organisasi gerakan sosial dapat berupa aktor dan uang. Pengorganisasian aktor Gemuruh untuk selalu aktif dalam segala kegiatan akan semakin menarik masyarakat luas dalam pelestarian sumber daya kelautan dan perikanan yang mulai rusak. Mobilisasi orang dalam gerakan sosial kontemporer berukuran skala besar yang merupakan hasil teknik komunikasi terkini, birokratisasi organisasi dan dorongan serta inisiatif utilitarian (Singh, 2010: 136). Mereka mendapatkan akses untuk mengajak berbagai kalangan masyarakat untuk ikut bersama-sama melestarikan SDKP dengan kampaye lewat sosial media. Dengan adanya kesempatan yang Gemuruh manfaatkan media sosial mengundang 
ketertarikan bagi masyarakat luar dengan aksi yang mereka jalan.

\section{Daftar Pustaka}

BPS. (2015). Statistik Daerah Kecamatan Muncar 2015. Banyuwangi: BPS Kab.Banyuwangi (2003). Perda Kabupaten Banyuwangi No 35 Tahun 2003 tentang Penetapan, Pelestarian dan Pengelolaan Kawasan Laut Lindung Perairan Kayu Aking di Muncar Kabupaten Banyuwangi.

Kusumah, Maulana S. (2015). Perjuangan Nelayan Atas Laut: Studi Tentang Kontruksi Relasi Nelayan, Pelembagaan Nilai Konflik Dan Resileinsi Sosial-Ekologis Nelayan Muncra Banyuwangi. Malang: Disertasi Program Pasca Sarjana Ilmu-Ilmu Pertanian Fakultas Pertanian Universitas Brawijaya.

Maarif, Syamsul. (2010). Perilaku Kolektif dan Gerakan Sosial. Yogyakarta: Gress Publishing

McCarthy, John D dan Mayer N Zald.(1977). Resorce Mobilization And Social Movements: A Partial Theory. The American Jurnal of Sociology Vol 82 (6): 1212-1241

Satria, Arif. (2009). Ekologi Politik Nelayan. Yogyakarta: LKiS Yogyakarta.

Silaen, Victor. (2004). Gerakan Sosial Baru di Toba Samosir: Studi Kasus Gerakan Perlawanan Rakyat Terhadap Indorayon Periode 1983-2000. Jakarta: Disertasi Program Pasca Sarjana Program Studi Ilmu Politik Fakultas Ilmu Sosial dan Ilmu Politik Universitas Indoensia.

Singh, Rajendra. (2010). Gerakan Sosial Baru. Yogyakarta: Resist Book

Snow, A David dkk.(2004). The Blackwell Companion to Social Movement. United Kingdom: Blackwell Publishing.

Sukmana, Oman. (2013). Kovergensi Antara Resource Mobilization Theory Dan Identity-
Oriented Theory Dalam Studi Gerakan Sosial Baru. Jurnal Sosiologi.

http://www.greenpeace.org/seasia/id/Pag eFiles/533771/Laut\%20Indonesia\%20dala

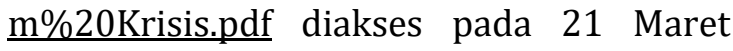
2016 pukul 20.20 WIB 